CATALAN REVIEW

Catalan Review

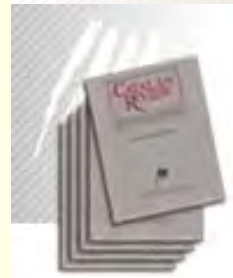

You are accessing the Digital Archive of the Catalan Review Journal.

By accessing and/or using this Digital Archive, you accept and agree to abide by the Terms and Conditions of Use available at http://www.nacs-

catalanstudies.org/catalan_review.html

Catalan Review is the premier international scholarly journal devoted to all aspects of Catalan culture. By Catalan culture is understood all manifestations of intellectual and artistic life produced in the Catalan language or in the geographical areas where Catalan is spoken. Catalan Review has been in publication since 1986 .
NORTH

AMERICAN

CATALAN

SOCIETY
Esteu accedint a l'Arxiu Digital del Catalan Review

A l' accedir i / o utilitzar aquest Arxiu Digital, vostè accepta i es compromet a complir els termes i condicions d'ús disponibles a http://www.nacs-

catalanstudies.org/catalan_review.html

Catalan Review és la primera revista internacional dedicada a tots els aspectes de la cultura catalana. Per la cultura catalana s'entén totes les manifestacions de la vida intel lectual i artística produïda en llengua catalana o en les zones geogràfiques on es parla català. Catalan Review es publica des de 1986.

\title{
Gertrudis and the Creative Modesty of J. V. Foix C. Brian Morris
}




\section{GERTRUDIS AND THE CREATIVE MODESTY \\ OF J. V. FOIX}

C. BRIAN MORRIS

J. V. Foix knew exactly what he meant when in the letter to Clara Sobirós that prefaces his Obres poètiques he described each poem as "un crit de llibertat" and defined the poet as a "mag, especulador del mot, pelegrí de l'invisible, insatisfet, aventurer o investigador a la ratlla del son". ${ }^{1}$ His consciousness that he was an adventurer with words made him incorporate into Gertrudis the names of real people, whose achievernents nurture the aspirations of a potential creator. Such names as Miró and Folguera, Riba and Handel may strike one initially as odd in a work devoted to and unified by a fictional figure, the remote Gertrudis. Teasing and inaccessible as she may be, she represents his dream; she is his creation, his match for the four famous literary heroines whose names are written by an invisible hand in "Diari 1918" above each of the four windows that open by magic in the walls of the tennis court: "Ofelia, Virgínia, Laura, Julieta" (14). And in "Sense simbolisme" Gertrudis bores her way into our sensibility with the piercing scream she utters when her admiring, and very human, poet, pinches her bottom; and the poet confirms her individuality and acknowledges mockingly the exaggeration indispensable to reverential love poetry when he makes it clear that "cap compositor no ha escrit ni escriurà una nota equivalent al crit de Gertrudis llançat, a mitjanit, a plaça oberta" (24).

${ }^{1}$ Obres poètiques, Barcelona, Edicions Nauta, 1964, 8. All page references will be to this edition. 
The care with which Foix names newspapers such as $\mathrm{La}$ Vanguardia (20) and La Publicitat (30) and the unnecessarily pedantic precision with which he identifies the "poeta LópezPicó", "el poeta Folguera" (22), "el pintor Joan Miró" (30), and "l'arquitecte Ràfols" (29) establish creativity as an ideal and as a model against which to measure himself: their collective fame and stature throw into relief his own pigmy stature, summarized in the simple but telling phrase with which he ends "Sense simbolisme. Gertrudis": "la meva poquesa" (19). This conscious humility in the shadow of greatness is translated into a fantasy of shrinking at the end of "Conte de Nadal", where Foix relates: "Petit, insignificant, em vaig arronsar dins un caixó ple de closques d'or" (30); another vision, at the end of "Sense simbolisme. Gertrudis", reduces his body to that of a child, while his head "es mantenia amb els seus vint anys escapadissos" (19). With his body and his head out of synchronization, Foix apes the "tres cavallers" in "Notes sobre la mar" by rushing to don the solemn uniform of "el vestit negre, el copalta, els guants" and to round off the effect by drawing "amb carbó, tres amples arrugues al front" (25). Much of the poignancy of Foix's visions derives from his own awareness that he cannot be older or wiser than he is, that his dreams are dreams, and that he may admire others but must rely on his own imagination and resourcefulness to devise a manner that is personal and significant at the same time. In "Diari 1918" he juxtaposes his images of his rival, his horse, and Gertrudis only to decide that what he was really looking at was something completely different: "un fal-lus de pedra, gegantí, erigit en edats pretèrites"; when the would-be archaeologist and cryptographer stretches out on the sand to decipher the inscription, he himself corroborates his statement that it was "una llegenda indesxifrable" by finding before him "el meu paraigua" (15). 
This umbrella deflates his own aspirations and pretensions as graphically as the cardboard nose and the "imponent diccionari de sinònims sota el braç" which advertise and deride his pretentiousness when he goes for a walk on the quayside in "Notes sobre la mar" (24). The implication is clear: poets like Folguera, Riba, and López-Picó would never need to walk around with a dictionary of synonyms under their arm; yet Foix's humility is self-serving: if all the creators he names exist or have existed in this world, he exists by paying homage to their achievements and making them a part of his. They become essential actors and props in his pursuit of an individual voice, of an identity reflected in the roles he adopts: of the jealous lover and of the warrior in "Diari 1918", of the "heroi de cinema" in "Conte de Nadal" (27). Although Foix mocks the creator behind the image of himself "arrossegant un piano de maneta" (14), he confronts in Gertrudis the theme and challenge of creating with words something original and meaningful. In "Conte de Nadal" his conversation with the nightwatchman moves from a simple exchange of foreign cities into a recital of names and sounds which disintegrate into syllables of fragmented nonsense; these acknowledge and reject the repetitive word-play explored by Dada and by Surrealist poets such as Robert Desnos, who in Rose Selavy (1922-1923) essayed mock definitions like "L'acte des sexes est l'axe des sectes"; the danger of becoming what Desnos identified with typographical emphasis in L'Aumonyme (1923) as

syllabes

Prisonnier des

et non des sens 
is one that Foix perceived and avoided. ${ }^{2}$ His dialogue with the nightwatchman merely identifies the possibilities of a world of fantasy, which breaks down before the inadequacy of words to maintain and nurture that fantasy; the passage contains an experiment with words only to acknowledge the inadequacy of that experiment:

-Això no és cap palau il-luminat, ni als eucaliptus hi ha joguines, ni els arbres són eucaliptus - exclamà el meu guía —: Això són els jardins Giusti de Verona. - No - vaig observar jo - : És la vil·la Giustiniani, a Pàdua. - Tampoc - respongué el vigilant —: És el remple de Karnak i ens trobem al cor de l'Egipte. Mentalment, jo confegia noms de ciutats i de contrades exòtiques, amb dificultat: Safed, Baalbek, i, d'esma, recitats en veu alta i amb llarga cantarella: - Seràtov, Sarajevo, Sasebo, Bashkir, Kirkuk, Kuban, Bangkok, Kodok. El vigilant clogué els ulls i digué: - No, no: Nak, Nak, Nak... Nagpur, Nak, Nak... Nakhitxevan. I jo, a continuació: $\mathrm{Pp}$; no, ans: $\mathrm{Dj}, \mathrm{Dk} .$. Havia perdut, però, el sentit de les vocals, n'ignorava la valor $i$, àdhuc, la grafia (28).

More challenging than this recital of staccato and ever more nonsensical sounds is his answer, in the form of the rhetorical question with which he talks to himself in Gertrudis, to the mundane sight of the sky as "només un trist miratge de la mar". "¿Què em pot sorprendre", he asks in innocent preparation of what is to follow, "si avui he vist saltar de cop els lloms dels meus llibres i he descobert la putrefacció cancerosa que destrossa llurs entranyes?" (15). Foix does not specify whether he has in mind the books of others that are in his possession or the books of his that he has not yet written; but this disturbing ambiguity does not obscure the fact that books are at the core of this graphic vision and that what generates it is the conviction that literature, in the guise of books that are both fissile

${ }^{2}$ Desnos, Corps et biens, 2nd ed., Paris, Gallimard, 1930, 31, 44. 
and highly susceptible to infection, is disturbing both to the author and to the reader.

In Gertrudis Foix conveyed through fantasy and phonic play the stylistic and aesthetic concerns he explored coincidentally in critical essays with such direct titles as "Algunes consideracions sobre la literatura d'avantguarda" (1925), which he elaborated into "Algunes consideracions sobre la literatura i l'art actuals" (1927). Three fundamental features emerge from these critical essays, which complement and help to identify the distinctiveness of his creative writings: his intimate but unostentatious knowledge of the basic canons and achievements of Dada, Futurism and Surrealism and his familiarity with the works of such diverse writers as Poe, Blake, Valéry, Lautréamont, and Maeterlinck; his amused and ironic detachment from the Surrealists, whom he proposes to leave "en llur orgia: follies de neòfit!"; and his contention that his prose pieces contain their own pace, coherence and inner logic, that they derive from an "idèntica infrangible unitat com la dels catorze versos d'un sonet". 3

These essays do not illuminate the content of Gertrudis; their assurance matches the confidence and eloquence with which Foix remained faithful to his own voice and manner during the nine years in which he composed the prose pieces that comprise this work. While individual elements and the cohesive factors of tone and style create the illusion that the prose pieces were conceived in the same state of mind and written within a single period of gestation, we know that he kept faith with the manner and with the imaginative vigor displayed so confidently in his first publication, "Plaça Catalu-

3 The first essay was published in Revista de Poesia, no. 2 (March 1925), 65-70, the second in L'Amic de les Arts, no. 20 (November 1927), 104-106. 
nya-Pedralbes". Under the more ostentatiously literary title "Singular narració", that piece appeared in 1918 in an issue of the magazine, Trossos, that, founded by J. M. Junoy, he himself directed. With reproductions by Paul Dermée, Miró, and E. C. Ricart and poems by Reverdy, Soupault, and Ezio Bolongaro (the last two translated by Foix), that particular issue gives an excellent idea of the diverse and novel manifestations of European art and letters near which the young Foix chose to operate. His knowledge of such distinct and distinctive poets as Soupault and Bolongaro helped him to hone his own manner, so that the prose pieces of Gertrudis reflect decisions that explain their likeness not to the Italian Futurist but their affinity with the prose of Lautréamont, or Soupault, whose "Poema cinematogràfic. Indiferència" contains in its version by Foix the simply narrated metamorphoses so recurrent in Gertrudis: "M'assec sobre un banc", imagines Soupault. "Compareix un home que es canvia en dona, després en vell."

While endorsing and aiding through his Catalan renderings the innovations of fellow Europeans, Foix was practising his own revolution as he responded in his distinctive manner to what Apollinaire called in 1918 L'Esprit nouveau et les poètes; the illusion of naturalness, of everyday routine uplifted and upgraded, belies Foix's achievement of writing in Catalan. His prose pieces dovetail into a particularly rich genre in French literature represented by such imaginative practitioners as Baudelaire and Lautréamont, and Foix paid tribute to the latter by translating into Catalan a passage from the first chant of Les Chants de Maldoror. ${ }^{5}$ Ideally, he should also dovetail into the equally

4 Trossos, Segona sèrie, no. 4 (March 1918).

5 "La complanta del gossos del Comte de Lautréamont traduïda per J. V. Foix", L'Amic de les Arts, no. 16 (July 1927), 54. 
rich Spanish genre of prose poems whose variety is demonstrated in the substantial anthology El poema en prosa en España. ${ }^{6}$ However, this anthology has no place for the Catalan language, even though it was published in Barcelona, and for that reason Foix would no doubt feel that he did not belong in it. His prose pieces therefore establish their own standards and proclaim their uniqueness through his flexible, elegant, and plastic use of his language, which is as much a protagonist within them as the Catalan writers, artists, and architects named by Foix. Outside Gertrudis, his homage to Pompeu Fabra, who guided him when "Ja vagabundeja prou la meva imaginació", is matched inside the work by the collective phrase of pride - "nosaltres, els catalans" - with which he rounds off in "Conte de Nadal' his list of "noms pedants: Brunelleschi, Blois, Pirandello i, àdhuc, Pitàgoras o 'nosaltres, els catalans'..." $(30)^{7}$ The humility explicit in his immediate comment "No em reconegueren" does not inhibit him from sharing vicariously in their collective fame by drawing them into his recognizably Catalan orbit. One of the many attractive features of Gertrudis is the openness with which Foix advertises the local setting by naming streets and townships, like the "carrer de Sant Vicenç" in "Pepa, la lletera" (33) and "Molins de Rei" in "Conte de Nadal" (27). While this toponymy underpins the work, it also challenges us to join him in seeing its wonder; the professional geographer has to state that "Al séu terme, sota Sant Pere Màrtir, hi ha lo dipòsit de les aygües del Llobregat, quina màquina elevatoria es a Cornellà", but only a poet has the right to declare in "7 h. 50-11 h. 50", as if it were

${ }^{6}$ Guillermo Díaz-Plaja, El paema en prosa en España. Estudio crítico y antologia, Barcelona, Gustavo Gili, 1956.

7 Foix, "Pompeu Fabra", in Catalans de 1918, Barcelona, Edicions 62, $1965,32$. 
verifiably correct, that "Un monstre mitològic, cavalcant el seu cavall alat, branda, al cim de Sant Pere Màrtir, un manyoc de números esgrogueïts de 'El Mundo Ilustrado' ( $1^{\circ}$ època) i il-lumina els flancs de la muntanya." $(21)^{8}$

This particular mountain shares with many concrete details the function of authenticating through familiar details and actual places incidents that are unrealizable and of creating an unstable setting appropriate to the elusive, capricious Gertrudis. She is his version of the inaccessible and playful beauty idolized by Petrarch and by so many others; suggestive of her infidelity, the question with which Foix ends the collection - "On vas passar aquella nit, Gertrudis?" - merely closes the cycle of solitude opened by the poet's first words: "He malferit en duel el teu amant". The remoteness of Gertrudis may echo strongly a central theme of love poetry, but it pays Foix the dividend of stressing the loneliness of any aspirant, whether to love, companionship, or literary fame; it also allows him to create for her an appearance whose inconsistency undermines her magnetism: the "belles llaçades escoceses" that held her hair the first time he saw her "veure a l'oratori del col-legi de monges" (28) have been replaced by "les mitges vermelles de Gertrudis" (26); and the silver throne on which he imagines her seated (16) is countered by a numbered park bench whose crimson color in no way disguises its ordinariness (17).

The religious school and the silver throne belong to a strong religious frame of reference by means of which Foix relates his prose fantasies and the spiritual experiences which

${ }^{8}$ Cels Gomis, Provincia de Barcelona: Volume 5 of Geografía general de Catalunya, dirigida por Francesch Carreras y Candi, Barcelona, Albert Martín, 1913-1918, 63. 
underlie them to the routine and terminology familiar to so many of his readers. Churches, convents, and cathedrals form part of the architecture of Gertrudis; nuns, like the scolding Sor Roser in "Pepa, la lletera", match in this life saints and angels, and embody the faith demonstrated, and lightly mocked, by Foix when he narrates in the same piece: "se sentí un batec d'ales dolcíssim, i de cada obertura en sortí un àngel" (23). The familiarity of these elements is underpinned by Foix's use of the Church calendar, which, as it leads us from the birth to the death of Christ, makes us question its meaning for the poet, who does state in "Conte de Nadal" that he tried "inútilment, de cantar. Hosanna!, hosanna!"' (30). One of the questions he then addresses to the shepherd - " ¿Veieu com sant Josep cenyeix la seva cintura a l'americana i no duu alta la trinxa dels pantalons?" - shows the need he felt to leaven with humor his memories of religious ceremonies, particularly the solemn rites and processions of Maundy Thursday, whose recurrence in this work shows the deep imprint registered by his sensitive and impressionable mind. However enterprising his method, the shorthand notes he took in "Diari 1918" of the "sermó de les Set Paraules" (14) would have recorded no change in their content or interpretation, so that when transcribed they would have told him what he already knew, that, in the case of the fifth word, "Tan espantoso es el suplicio de la sed, que su misma intensidad apagaría los demás dolores, si la sensibilidad de Cristo no hubiera sido dispuesta para padecer sobre toda humana resistencia." In "La vila" Fra Fèlix may make for the castle "carregat amb les bicicletes", but he does so "entre una nova fumerola d'encens" in a town displaying "els gonfanons

9 Jenaro Xavier Vallejos, "Quinta palabra: ‘Tengo sed!' ", in "Las siete palabras", La Esfera. Ilustración mundial, no. 744 (7 April 1928), n. p. 
del Via Crucis" (20); and in "Plaça Catalunya-Pedralbes" the tram inspector becomes an austere priest when he makes the poet gird on "damunt la carn viva, un cilici" and converts a ride in a tram into the poet's own Via Crucis as he reads, "a través de ferides sagnants, un poema de Ramon Rucabado."

Taking his cue from Fra Fèlix, who emerged from a trapdoor "enmig d'una fumerola d'encens" (20), and from the "pastor anglicà" who in "Notes sobre la mar" wanted to "demostrar com els miracles més bells s'han esdevingut a la mar" (24), Foix set out to work his own miracles by substituting for old rituals new routines located within the structures and settings of real life, such as churches, streets, tennis courts, and barber shops, and by reassembling the many concrete elements that incrust his poems.

Foix has fashioned in Gertrudis a sensuous world, echoing with hoofbeats and music, perfumed with flowers, incense, and Gold Flake cigarettes, firmly shaped as it moves from town to shore, strongly colored as black (seen in a horse, a flag, and the formal dress of the three gentlemen aped by the poet) stands out against the bold shades a "flor vermella" (13) and the "enagos carmesî" (30). Horses, flags, curtains, together with birds and walls, are distinctive features of Gertrudis; the poet may issue the warning "Sense simbolisme" in the titles of two pieces, but no reader with a modicum of imagination can remain insensitive to their recurrence or to the way in which some of them appear before us; Foix may or may not have been aware that gloves, in Cirlot's words, "since they are worn on the hands, derive their symbolism from them"; the "guants de cautxú" he put on during his tryst with Gertrudis reveal the intuitive knowledge he shared with Apollinaire, who wrote in Calligrammes "Les gants sont morts près d'une pomme", that commonplace objects can acquire an eccentric, even sinister, 
significance in improbable surroundings or unlikely circumstances. ${ }^{10}$

The ability to invest the commonplace with mystery is a gift displayed by Foix through a variety of devices, some syntactical, others narrative; the illusion of logical discourse is fostered by explanations that disconcert more than they clarify, as in the poet's statement to Gertrudis that "Però perquè duus el vestit carmesí, te'n rius" (13), and by conditional sentences in which the protasis clashes with the apodosis, as in his strange avowal (also in "Diari 1918") that "Si no hagués anat carregat d'un feixuc bidó de vernís, inelegant, m'hauria estret més el nus de la corbata." (16) Disconcerting in a different way is the question that can receive no answer, like "¿Què hi feia aquella cadira Lluís XV al portal de ca l'espardenyer?" (16). Self-contradiction becomes a means not simply of unsettling the reader, who has to remain passive before a sequence of possibilities presented, sifted, and rejected with a rapid decisiveness that stands in conflict with the poet's indecision; we cannot be sure that the poet is telling us the truth when he relates in "Diari 1918": "Et vaig sorprendre quan el teu nou amant et donava un estoig magnífic. No era, però, un estoig: era un llibre; ni era tampoc el teu amant ans jo mateix que et regalava una capsa de tubs d'aquarel-la amb les colors de l'iris." (14)

The disappearance of elements which the reader has been invited to visualize, such as the houses in "Pepa, la lletera" and the weapon and flower in "Diari 1918", confirms his presence in a mystifying world that obeys its own laws and corroborates

${ }^{10}$ J. E. Cirlot, A Dictionary of Symbols, 2nd ed., trans. Jack Sage, New York, Philosophical Library, 1971, 119; Apollinaire, "Les collines", in Calligrammes, Paris, Gallimard, 1966, 35. 
its existence by reflecting its own images in mirrors or, in the latter piece, in the eyes of a hanged man. "On és l'arma? On és la flor?" asks the poet. "A l'home de la carota de gegant l'he vist avui penjat al portal de la Seu de Manresa fent una ganyota agònica. Però al fons del gorg de les seves pupil-les t'he vist a tu amb la flor als llavis i l'arma al braç." And the question with which he ends the passage - "Per què m'has deixat, Gertrudis?" (15) - makes us realize that the disappearance of the weapon and the flower was an omen of and prelude to Gertrudis's desertion. In the same piece, the disappearance of his tennis companion and the consequent transformation of "el fiacre" into "la desferra secular d'una antiga carrossa reial" (15) is a simple example of the metamorphoses so earnestly cultivated by the Surrealists; the surrender "aux associations d'idées" undertaken by Aragon's Anicet generates a sequence of images in which "cette lame devint la lune, la courbe d'un bras nu, l'arche d'un pont." 11 Foix manages to make the transformations in which he would have us believe far less methodical and doctrinaire; through them he remodels the world as he knew it, evaluates the reconstruction, and adjusts his vision to accord more with reality that with fantasy, which may produce in "Conte de Nadal" the attractive images of a castle and a palace only to see them supplanted by the poet's common-sense realization that they are no more than "una tenebrosa caserna de carrabiners" and "una cabana de pastor" $(27,28)$.

This display of possibilities, all of which we have to consider, generates its own momentum and obeys its own logic in a passage of "Diari 1918" that describes a perfect arc from a girl's buttock to the haunch of the poet's horse. The rumor that Gertrudis is jealous of that girl's buttock inspires in the

11 Aragon, Anicet ou le panorama, 14th ed., Paris, Gallimard, 1951, 175. 
poet not a sequence of reasons acceptable to our minds, even though he does prepare us with "Però", but a flow of images receding from the mirror through curtains into a passageway with an extraordinary picture depicting the particular tortures inflicted on girls who study themselves in the mirror we have just been shown:

Diuen que estàs gelosa de la gropa de la noia de la lletera. Però he estat a casa seva $i$ he vist la consola amb el mirall on se pentina. A les pregoneses del mirall, dues amples cortines vermelloses cobricelaven l'entrada a un passadís al fons del qual hi havia un quadre. Una vella litografia hi representava les tortures a què el diable sotmet les noies que, en tornant de sarau, a mitjanit, es contemplen al mirall. M'ha torbat tant, que he tardat a adonar-me que el marc del mirall i el marc de l'entrada al passadís no eren sinó el bastiment de l'entrada a l'establa on senyoreja la gropa del meu cavall. (14)

Foix's realization that the two frames he had mentioned and purportedly seen were really a third frame he has not named brings him and us back to more familiar and secure surroundings as it leaves us staring at the solid image of a horse's rump. What Foix has done here as elsewhere in Gertrudis is to make into a feature of his fantasies his awareness that they are fantasies, that he is creating pictures and scenes which he sometimes frames in windows or places behind theatrical curtains. Foix knows what he is doing; he realizes that imaginative freedom is an illusion, that the mind finds its own barriers erected in this work by his awareness of the "inimaginables paisatges desolats" pictured in the playing cards at the end of "Diari 1918" (17) and by the "figures grotesques d'éssers mitològics no catalogats" and "dolça música emesa per instruments imprecisables" seen and heard in "Conte de Nadal" (29). One of the most honest and dignified discoveries confessed 
by Foix in Gertrudis is that dreams provide no solution to a person's solitude: they illustrate and confirm it by showing their starting-point to be the reality from which the mind escapes. Foix advertises the ordinariness of that starting-point in such terse, no-nonsense titles as "La vila", "7 h. 50-11 h. 50", "Pepa, la lletera", "Sense simbolisme", and "Plaça CatalunyaPedralbes", which advertises his use of and tribute to the line of communication described in the sober prose of our geographer: "Aquest poble està unit a Barcelona per medi d'un ferrocarril y d'un tranvía elèctrich. Abdós surten de la Plaça de Catalunya ..."12 And in "Sense simbolisme. Gertrudis" he leavens imagination with wry humor to create a fantasy whose conventional source - a lover's visit to his mistress's garden - is consistently mocked and shown to be more of an obstacle course than an idyll. The promise of a ride on the poet's ubiquitous horse to Gertrudis's garden and to her arms collapses under the pressure of a series of incidents in which nature's accomplices of tender love - the moon, nightingales, stars, the intoxicating perfume of flowers - are disengaged from their traditionally sentimental function: without telling us how, he shuts the perfumes of the acacias in "un estoig fermat amb argolla de dragonita legítima" (17); he hears "el cant gentil d'un rossinyol" on the telephone; Gertrudis unhooks the stars one by one; and the moon, which paralysed his hands as he was about to kiss Gertrudis, reduces the concrete world they inhabit to a flaccid mass from which they escape into the graceful and consoling symmetry of a neoclassical building:

La lluna, inflada fins a l'esberlament, penjava damunt nostre en amenaça feixuga i la seva claror extrema estovava el banc del nostre deport fins a

12 Cels Gomis, Provincia de Barcelona, 61. 
tornar-lo elàstic. Ens vérem obligats a refugiar-nos sota un templet neoclàssic i a cercar l'ajut del meu cavall-llanterna per a fugir i alliberar-nos del tafur amollidor. (18)

The impulse to flee is natural and an essential feature of many melodramas, but in no melodrama has a horse been spurred on by an instrument so indicative of the writer as a fountain pen. This writer has two more surprises for us in his deflation of the sentimental situation against which we must project his piece: the first is when he declares himself cured of "una amnèsia crònica", a forgetfulness that made his visit possible. Had he remembered that Gertrudis had been seduced by a black man in a place as familiar and conspicuous as "la plaça-mercat de Sarrià", he would not have paid court to her by emulating Calixto (or Romeo). The second surprise is to find Gertrudis reduced to "un manyoc de parracs perfumats", which represents the disintegration of his illusions as graphically as the locks of her hair he will hang from his balcony. His wandering "a l'atzar" is an escape from his own delusion and from the sensual impulses which underlie his fantasy; the locks of her hair hanging from a balcony are an epitaph to the fascination Gertrudis exercised on him and to the companionship that, however threatened and shortlived, has been replaced by solitude and by the recognition of "la meva poquesa".

The prose poems of Gertrudis present an intriguing blend of subjectivity and detachment as Foix spins his dreams and looks at himself spinning them; while they demand that we consider the personality of the poet who creates them, the fantasies operate on a level of allegory and erect at the same time a screen of privacy appropriate to the young writer who never felt it necessary to tell his family about his literary activities. His secure and stable daily life throws into relief the boldness 
of the literary adventure he undertook in the writings that coalesced in Gertrudis. In 1923 a Catalan newspaper protested against "una hostilidad injusta contra la lengua catalana". 13 Foix no doubt sensed the same antagonism, but protested in a more positive way: his writings stand as a tribute to his language, to his land, and to some of its most distinguished creators, at the same time as they document the richness of his imagination and the independence of his mind and tastes. His mature recognition that everyday life and the plane inhabited by the imagination are separate, that the level on which he sets his stories starts from and runs parallel with real life but cannot supplant it, influences his manner, which is fluent, assured, and free of the excesses he criticised in the Surrealists. As the first work of a young man, Gertrudis demonstrates extraordinary composure and control as each prose poem develops its own pace and finds its own length in accordance with the demands of the narrative pretext, a brief but magical incident in "La vila", a sustained assault on sentimentality in "Sense simbolisme. Gertrudis". As proof of the power of the imagination, Gertrudis demands respect; yet Foix's capacity to turn his ironic gaze at himself so that we see him as a lover, lonely but decisive, and as an aspiring creator, modest but productive, commemorates a young man confronting himself and his vocation. The young writer who imagines himself spurring a horse with a pen and strolling with a dictionary of synonyms under his arm plots a firm trajectory toward the mature poet who in the first line of L'Estrella d'En Perris, published in 1963, declares "Era jo sol en un vagó de tren, voltat de llibres" (231). In surrounding himself with the products of his craft, Foix shows

13 The protest, made by La Veu de Catalunya, was reported in El Sol on 7 February 1923 under the heading "La lengua catalana". 
us the constancy of his dream and the fascination exercised on him by the written word. His is a dream pursued with imagination and with integrity, and Hispanic letters would be poorer without it.

\section{BRIAN MORRIS}

UNIVERSITY OF CALIFORNIA, LOS ANGELES 